\section{Ankara University Faculty of Educational Sciences Journal of Special Education}

2022, 23(4), 751-773

\section{RESEARCH}

Recieved Date: 04.01.20

Accepted Date: 02.01.22

Online First: 22.02.22

\title{
Major Tendencies in Special Education Within the Framework of Educational Technology Between 1960-2019
}

\author{
Nazire Burçin Hamutoğlu $\left(D_{1}\right.$
}

\author{
Onur İşbulan $\mathbb{D}^{2}$
}

Mübin Kıyıcı ${ }^{\circledR}$

\begin{abstract}
Introduction: Amazing technological advances in transportation, health, communication, and education continue to facilitate our lives from past to present. Considering the developmental and professional characteristics of students with special needs; It is thought that educational technologies have a very important place in enriching the learning and teaching processes in terms of gaining competence.

Method: Previous studies on special education and educational technologies indexed in the Education Research Index (ERIC) database between 1960-2019 were reviewed with scientometric methods, and in this context, 22049 studies with "Special Education", "Educational Technology" labels are obtained. This study, carried out by using content analysis, is a descriptive/depictive study in terms of purpose.

Findings: One of the most important findings of this study is that the word "handicapped" was used in the abstract parts of articles in 1980s and early 1990s. However, it was later replaced with "disability". Another significant finding of the study is that computers are often used as a technology tool in special education. Accordingly, it can be said that studies from past to present have been focusing on school and there is a consistency in the articles on educational programs. It is thought that the computer software used in obtaining this result has an effect considering the results on trends in real life skills related to children and teachers who also play an important role in the study
\end{abstract}

Discussion: Based on the findings, it is recommended to future researchers to renew curriculum programs in this direction and arrange them by making use of technological development to include the target audience which is not only families but also teacher candidates.

Keywords: Text mining, education, evaluation, bibliometric analysis, special education, technology.

To cite: Hamutoğlu, N. B., İşbulan, O., \& Kıyıcı, M. (2022). Major tendencies in special education within the framework of educational technology between 1960-2019. Ankara University Faculty of Educational $\begin{array}{llll}\text { Sciences Journal of } & \text { 5pecial }\end{array}$ https://doi.org/10.21565/ozelegitimdergisi.835696

${ }^{1}$ Corresponded Author: Dr., Eskisehir Technical University, E-mail: nbhamutoglu@ eskisehir.edu.tr, https://orcid.org/00000003-0941-9070

${ }^{2}$ Assist., Prof, Sakarya University, E-mail: oisbulan@ @akarya.edu.tr, https://orcid.org/0000-0001-5326-071X

3Prof., Sakarya University, E-mail: mkiyici@sakarya.edu.tr, https://orcid.org/0000-0001-9458-7831 


\section{Introduction}

Considering the developmental and professional characteristics of students with special needs; it is thought that educational technologies have a very important place in enriching learning and teaching processes in terms of gaining proficiency. Especially, when it comes to individualization of the learning materials, methodtechnique, and the contents offered, which are based on the student-centered learning-teaching processes in special education; the dynamic of educational technologies that will work in meeting the needs of students with different learning needs are very important (Öngöz \& Özel-Şanal, 2017).

Developments in educational technologies have always been in the center of attraction for many researchers and continue to be. In the literature, studies are reviewed with respect to their format, content, and method by using content analysis. They are categorized according to the subject, target group, preferred research model, data collection, and analysis methods as well (Caffarella, 1999; Erdoğmuş \& Çağıltay, 2009; Gökoğlu et al., 2014; Göktaş et al., 2012; Gülbahar \& Alper, 2009; Ma, 2000; Şimșek et al., 2008; Şimşek et al., 2009; Tosuntaş et al., 2019; Üstündağ, 2013). It is seen that those studies which are reviewed with content analysis method are doctorate theses, master theses, and articles. Findings related to the studies conducted in Turkey show that these studies focus on a specific subject rather than covering educational technologies (Gülbahar \& Alper, 2009; Şimşek et al., 2008; Şimşek et al., 2009) and that majority of them are quantitative studies in terms of the research model they utilize (Gülbahar \& Alper, 2009; Şimşek et al., 2008; Şimşek et al., 2009; Üstündağ, 2013). Additionally, there exist studies reporting that trends in educational technologies have changed over the years (Caffarella, 1999; Üstündağ, 2013).

The number of scientific studies which intend to present the current state of educational technologies both in Turkey and in the world is increasing each day. Üstündağ (2013) reviewed research trends in 133 master theses prepared by the departments of Computer and Instructional Technologies in Turkey between 2002 and 2007, by categorizing them with respect to university, subject, and the research model used.

The results of their study show that computer aided educational and teaching approaches were on top of the list until 2007. In the following years, researchers became disinterested in these topics. These theses which were also researched by many studies on computer aided education especially in the fields of science and mathematics lost their popularity as they were superseded by studies on distance learning. Their study also concluded that quantitative research models were preferred more compared to qualitative research models. They also reported that in these qualitative studies interview technique was used more than observation technique. To evaluate the doctorate theses on educational technologies completed by five universities (Anadolu, Ankara, Middle East Technical, Hacettepe and Marmara University) in Turkey in the last decade, Şimşek et al. (2008) reviewed 64 theses with respect to format, content, and method. The results showed that two thirds of the theses were conducted with experimental model using intermediate statistical techniques; rest of them were planned and conducted with general survey model and beginner level statistical techniques. It is also reported that most of the theses reviewed in their study were conducted with participants studying at formal educational institutions. They also stated that different data collection tools were used in accordance with the design of the research. Achievement and attitude scales were frequently used in experimental studies while case study and content analysis were used in survey studies. In the studies reviewed, it is stated that learning in computer systems is a predominant study subject of educational technologies. This subject is followed by studies that examine variables related to instructional design and learning approaches. Furthermore, the results suggest that there are serious internal and external validity issues in the theses reviewed. There are no studies on the aspects of educational technologies in Turkey.

Similarly, in their study aiming to evaluate the master theses on educational technologies, Şimşek et al. (2008) reviewed 259 master theses with respect to format, content, and method which were completed by nine universities between 2000 and 2007. The results of their study suggested that quantitative and qualitative aspects of the studies on educational technologies significantly differed. Quantitative research methods were preferred more while only one fourth of studies was qualitative. They also stated that most of the studies were conducted in survey model and the data tools used were generally questionnaires, tests, and scales. It was also reported in this study that majority of the samples $(75 \%)$ were adults and university students; descriptive statistical techniques were used to analyze the data. In a very limited number of experimental studies, intermediate procedural techniques were utilized. It was reported that computer aided teaching, alternative teaching-learning approaches, web aided learning, challenges in the utilization of educational technologies, internet-based learning, and distance learning 
were the most frequently studied subjects while there were serious internal and external validity issues in the reviewed theses. Their results were very weak regarding functionality and implications.

The general trends in special education research based on educational technologies is seen in the attitude of special education teachers towards assistive technologies (Alnahdi, 2014; Aslan, 2017; Bahçeci, 2019) and computers (Kışla, 2008). In addition to this, using digital books in special education (Öngöz \& Özel-Şanal, 2017) examining teacher candidates' technology usage competencies (Tatlı \& Akbulut, 2017), pre-service teachers' use of digital learning materials in special education (Karademir-Coşkun \& Alper, 2019), and the use of visual and interactive materials to solve the difficulties that students experience (Keser \& Özdemir, 2017) are among the trends in special education researches. Furthermore, Cumming and Draper-Rodríguez (2017) reveal the current situation and development trends of the application of computer-aided tools and software applications in special education, explaining that the research trends are examined in terms of the age of the learners, types of technology, types of disabilities, learning environments, and application areas.

Gülbahar and Alper (2009) thoroughly researched 149 articles published in five national journals during the last three years with the assumption that these journals contained the highest number of articles related to educational technologies. The articles were reviewed with respect to subject, target group, theoretical basis, sample selection method, sample size, type of the study, research method, data collection techniques and reference numbers. According to the results of the review, studies primarily focused on "e-learning" and distance learning; they were conducted at universities and focused on impact and integration more although there were a lot of research subjects and concepts in the field of educational technologies. It was also reported these studies had a lot of theoretical deficiencies. The convenience sampling method was primarily used. Another result was that the number of quantitative studies was higher than the qualitative studies.

Regarding the basic research trends, Caffarella (2000) analyzed 2689 doctorate theses which were conducted in the United States of America between 1977 and 1998 and how the research subjects evolved over the years. He continuously improved and updated the list. In 1988, he and his colleague Sachs first analyzed the doctorate theses which were completed in between 1977-1986 along with the ones completed between 1987-1988 (Caffarella, 1991). In a general review which Caffarella (1999) combined his latest study with other studies, he remarked that studies on computer aided teaching, instructional design, analogies, games, television, and video were predominant. He also stated that experimental studies were in a decline and studies on environment comparison became less popular unlike the qualitative studies.

The analysis of the studies shows that researchers aimed to reveal which subjects in educational technologies were predominantly researched and other aspects of studies such as the research methods used in the studies, selection of sampling, data collection and how the data were analyzed in the studies in a database (e.g. SSCI) (Göktaş et al., 2012), in internationally respected journals of educational technologies (e.g. Educational Technology Research \& Development-ETR\&D, British Journal of Educational Technology- BJET, etc.) (Klein, 1997; Ross et al., 2010), in national journals of Turkey which review educational technologies with respect to certain periods (Gülbahar \& Alper 2009), in articles presented at computer and instructional technologies symposiums (Gökoğlu et al., 2014) or in doctorate theses (Caffarella, 1999; Erdoğmuş \& Çağıltay 2009; Ma, 2000; Şimşek et al., 2008; Tosuntaş et al., 2019) and master theses (Costa, 2007; Erdoğmuş \& Çağıltay, 2009; Şimşek et al., 2009; Tosuntaş et al., 2019; Üstündağ, 2013). When the studies are analyzed, it is seen that the findings are obtained with content analysis. Additionally, it is seen that (Göktaş et al., 2012); 64 doctorate theses (Şimşek et al., 2008); 259 master theses (Şimşek et al., 2009), totally 460 articles were reviewed by the studies conducted in Turkey. In their study aiming to reveal subject, sampling and methodical trends in educational technologies in Turkey, Erdoğmuş and Çağıltay (2009) reviewed 248 doctorate and master theses while Tosuntaş et al. (2019) reviewed 148 master theses related to educational technologies and instructional technologies with respect to theme and methodology. However, a study conducted in the United States of America showed that the maximum number of doctorate theses reviewed related to educational technologies was 2689 (Caffarella, 2000). In the studies it is seen that historical developments occurring in educational technologies are studied together. However, these developments are not studied in relation to the developments and trends in other fields.

\section{Importance and Purpose of the Study}

Technologies of transportation, health, communication, and education continue to develop as an element that facilitates our lives from past to present. The most important developments in education generally occurs in special education. This fact is also supported by some studies suggesting that assistive technologies can help those who need special education gain skills and qualifications that they need to become self-sufficient to meet their 
needs in terms of special education (Sani-Bozkurt, 2017). Educational, cultural, economic, and social needs of the individual with special needs should be met in order to let them grow into self-sufficient, sociable, and productive individuals. Additionally, all services and facilities should be arranged according to their needs to facilitate their socialization. In this context, it is a highly desired situation in the society that those who need special education be self-sufficient and capable enough to take care of themselves, which is also the priority of special education for their integration into the society. Meeting this need is by all means closely related to the purpose of technology, but it also closely concerns the advancements in the period it is utilized. It is generally thought that educational technologies came to the forefront as personal computers began to enter our daily life (Doğan, 2010), but in reality they are parallel to the advancements in technology. İşman (2011) states that the computer is not the only educational technology that is used in scientific studies; hardwares such as television, radio, DVD and VCD, Internet, satellite technologies and other technologies are used as well.

In the light of this statement, the studies analyzed in the literature show that educational technologies are utilized in the field of special education (Çal, 2011; Heward, 2013; Karanfiller et al., 2017; Özak \& Avcioğlu, 2007; Sani-Bozkurt, 2017; Subakan \& Koç, 2019; Yaman et al., 2016). In the studies conducted, it is seen that the master theses in Turkey are reviewed with respect to various variables (Coşkun et al., 2014). Thematic trends and research methods in educational sciences and special education are depicted (Fazlığulları \& Kurul, 2012). The studies are conducted on the basis of objective paradigms; methodological and the thematic variety is limited. Considering the fact that there is not a tendency in social sciences to debate its own ontological problems stipulated by the general arguments that epistemological and methodological problems in social sciences should be eliminated (Schwand, 1990; Wallerstein, 2003) since there is not a significant trend in social studies for theoretical studies (Fazlıoğulları \& Kurul 2012), this study aims to report the developments in special education in the framework of educational technologies on a periodical basis. Analysis of the studies in the literature shows that the findings of these studies are obtained from a limited number of studies conducted in a certain limited period (e.g. last three years). However, changes in research methods caused by the advancements in technology are apparent. Now it is possible to review many multidisciplinary studies at once by using the new means of technology instead of reviewing a certain number of studies limited to a certain period with existing methods. The findings in this study are obtained from a holistic analysis of 1,738,046 studies which were conducted between 1960-2019 and indexed in ERIC database. Through the content analysis, research trends from past to present and how research subjects are changed over the years are determined. Trends to use educational technologies in special education are discussed in the study by reviewing the advancements in both fields. Reviewing and analyzing the changing methods and trends in the world, and also rethinking on the developments that occurred in educational technologies related to special education are important. This study seeks for answers to the following research questions:

1. When analyzed on a periodical basis between the years of 1960-2019, how are studies in the field of special education indexed by ERIC database distributed?

a. When analyzed on a periodical basis, how do studies in the field of special education differ in terms of number, abstract text, subject, and distribution of target group?

2. When analyzed on a periodical basis, how are studies in the field of education related with educational technology indexed by ERIC database distributed?

a. When analyzed on a periodical basis, how do studies related to the use of educational technologies in special education differ in terms of subject, content, and target group?

\section{Method}

This study was planned and conducted in accordance with the bibliometric analysis method in terms of purpose. It used content analysis method with a scientometric perspective. Big data and data mining techniques were used to understand trend and tendencies.

Data mining is one of the techniques used in big data analysis. Data mining is an analysis technique to obtain meaningful information from large sets of unstructured data resources, to reveal new patterns and to convert data into information (He et al., 2013; Tsantis \& Castellani, 2001). Among the standard methods of data mining are text classification, text clustering, ontology and taxonomy creation, document summarization, and latent corpus analysis (Feinerer et al., 2008). One of the aims of data mining is to extract key elements in large data sets and to identify the relations between these elements and summarize them (Davi et al., 2005). Fan et al. (2014) remark that not only big data and data mining process offer many opportunities, but they also bring many challenges. 
There are two different techniques which can be regarded as a road map in data mining processes. First, the road map proposed by Gandomi and Haider (2015) is shown in Figure 1. Secondly, the road map proposed by Chen and Zhang (2014) is shown in Figure 2.

\section{Figure 1}

Big Data Process

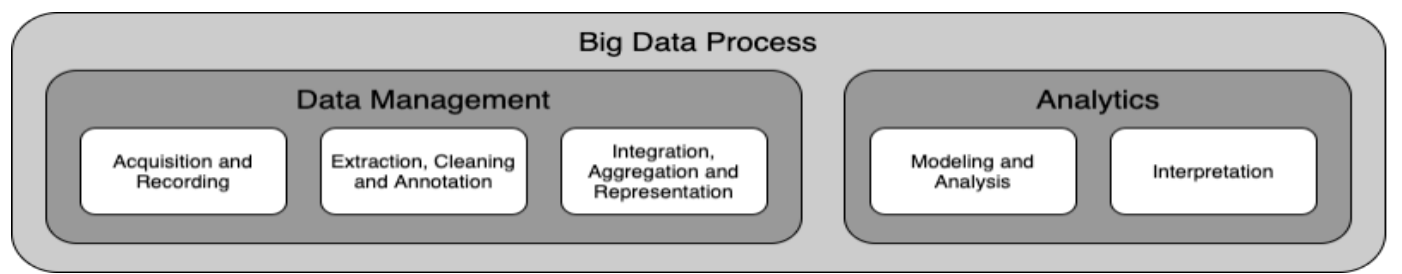

Source: Gandomi, A., \& Haider, M. (2015). Beyond the hype: Big data concepts, methods, and analytics. International Journal of Information Management, 35(2), 137-144.

\section{Figure 2}

Knowledge Discovery Process

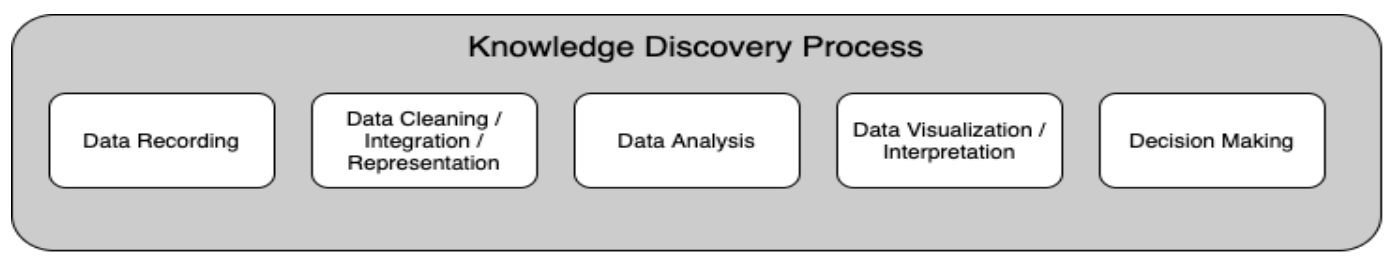

Source: Chen, C. P., \& Zhang, C. Y. (2014). Data-intensive applications, challenges, techniques and technologies: A survey on big data. Information Sciences, 275, 314-347.

\section{Research Process}

The theoretical universe of the study consists of the studies conducted on special education and educational technologies between 1960-2019. This study reviews the use of educational technologies in the field of special education on a periodical basis between 1960-2019 (can be seen in Figure 4). In this context, the number of studies indexed in ERIC (Education Research Index) with "Special Education", "Educational Technology" labels are obtained. Due to the size and diversity of the index structure in the ERIC, the ERIC database constitutes the selected index of the study. Accordingly, through the obtained data, word clouds are formed with the data by reviewing titles and abstract sections of 22049 articles. ERIC database index many types of research including journal papers, thesis and dissertation, classroom guides, opinion papers, etc. In this research, the journal paper research type as selection criteria was used. Other research can be without expert and reviewer evaluation but journal papers publish after reviewer evaluation. Because of that process journal papers were selected in the sample. The word clouds are interpreted considering the developments in educational technologies and their implementations in the field of special education. This study is a complete inventory since it includes all studies within certain limitations (Karasar, 2010). Figure 3 shows the annual and the cumulative number of studies indexed in the ERIC database between the 1960-2019 years. 


\section{Figure 3}

Annual and Cumulative Number of Studies Indexed in ERIC Database Between 1960-2019

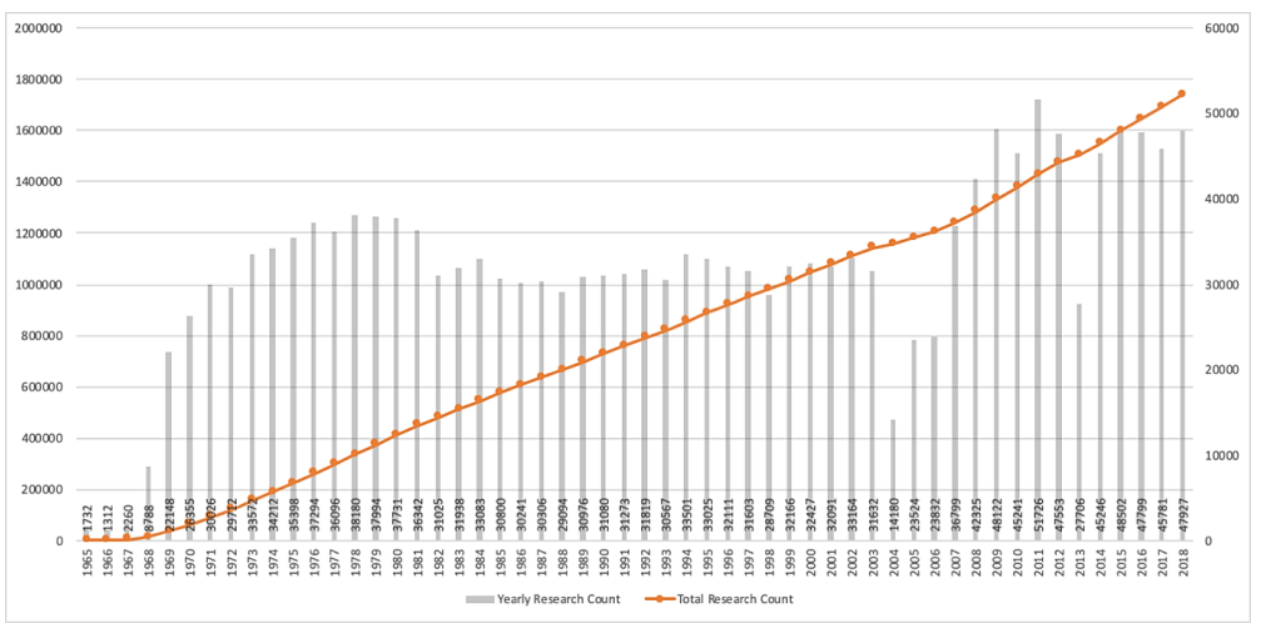

Within the scope of the study, it was aimed to review the articles indexed in the ERIC database in terms of different variables. To achieve this goal, articles indexed in the ERIC database are downloaded by years as a separate XML file from the (www.eric.ed.gov) download page of the ERIC index website and saved. To facilitate data analysis processes, data were transformed to a more program friendly version and saved as a data frame. After this stage, data analysis started. In the analysis phase level 1 keyword is set as "Special Education" and the level 2 keyword is set as "Educational Technology" from ERIC Descriptor. Based on this descriptor, studies were selected and further analyses were conducted on these studies. To obtain word clouds Python programming language and its' packages were used (such as The ElementTree XML API), Pandas (McKinney, 2010) and NLTK (Bird et al., 2009). In the method based on the data collection and analysis process of the study, the study of İşbulan et al. (2021) was used.

\section{Findings}

In this part, graphical definitions are made for the results. Special education and educational technologies studies are discussed together and separately. The graphical illustration of the articles on special education indexed in ERIC Database since the 1960s is presented is shown in Figure 4.

\section{Figure 4}

Articles on Special Education Indexed in ERIC Database Since 1960s

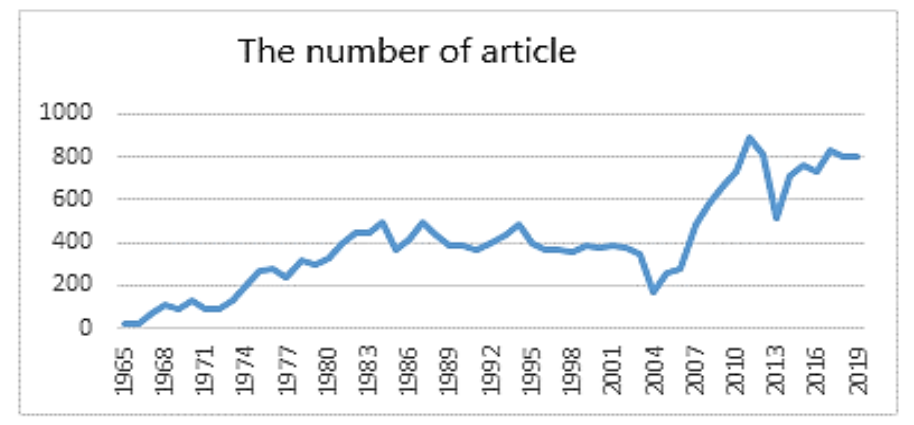

When Figure 4 is analyzed, it is seen that the number of articles on special education indexed in the ERIC database has been increasing over years. Even though there was a decline in the early 1990s until mid-2000s, the number of articles exponentially increased since 2005 . Especially during the last decade, it is seen that annually 750 articles on special education have been written.

\section{Analysis of the Abstracts of the Articles on Special Education Indexed in ERIC Database}

The trends in the text of the abstracts of the articles in special education indexed in the ERIC database are separated by analyzing the big data. For this separation, the most frequently used 10 words in the abstracts of the 
articles are analyzed and shown in a graphic. The graphical illustration of the analysis of the abstracts of the articles on special education indexed in ERIC database since the 1960s is presented is shown in Figure 5.

\section{Figure 5}

Analysis of the Abstracts of the Articles on Special Education Indexed in ERIC Database
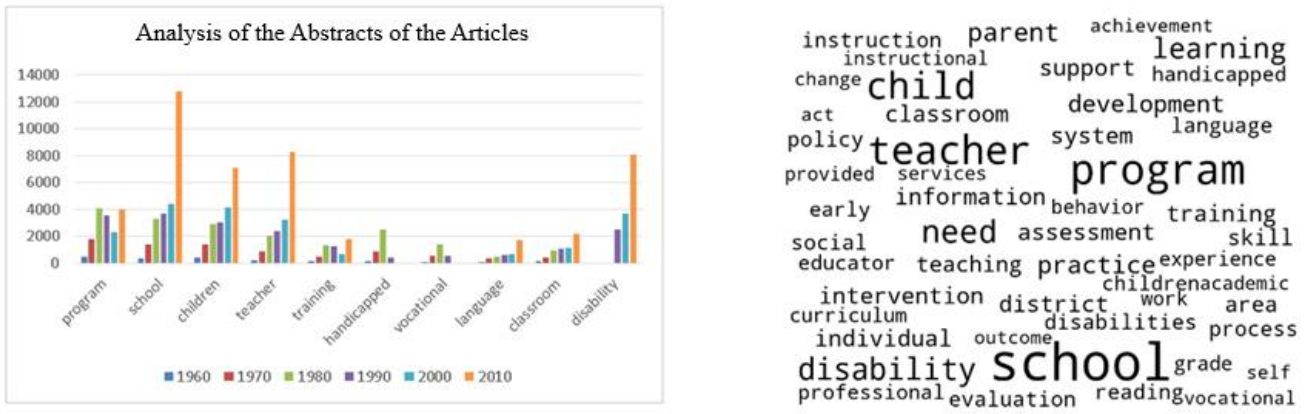

Analysis of Figure 5 indicates that "school" is the most frequently used word in the abstracts of the articles written since the 1960s. It can be said that the articles on special education have focused on school. The articles about programs have been consistent. Articles on teachers and students have an extensive place in the literature. In the 1980s and early 1990s the word "handicapped" was included in the abstract parts. In the following years, it was replaced by "disability". It can be said that the number of articles written in the field of vocational training in special education is very low in recent years contrary to the high numbers in the past.

\section{Figure 6}

Subject Distribution of the Articles on Special Education Indexed in ERIC Database

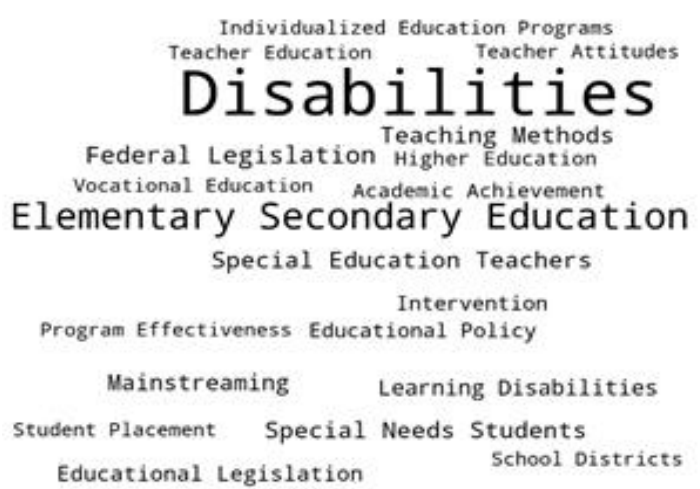

As it can be seen in Figure 6, the graphical illustration of the subject distribution of the articles on special education indexed in the ERIC database since the 1960s is presented. Accordingly, analysis shows that, in terms of subject distribution, studies conducted in the field of special education have focused on "disabilities" $(n=8026)$, "elementary secondary education" $(n=6954)$, "federal legislation" $(n=2422)$, "students with special needs" $(n=$ $2170)$ and "special education teachers" $(n=2159)$. However, "Teaching Methods", "Mainstreaming", "Learning Disabilities", "Educational Legislation" are the primary subjects studied in the field of special education. 


\section{Figure 7}

Target Group Distribution of the Articles on Special Education Indexed in ERIC Database

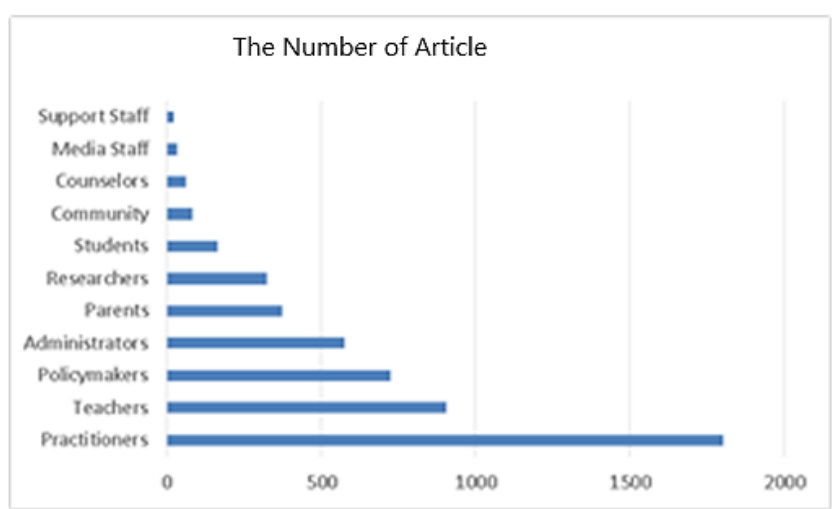

In Figure 7, the graphic of target groups of the articles on special education is presented. Figure 7 shows that the target group is "practitioners" in most of the articles. This is followed by the articles including "teachers", "policymakers", "administrators" and "parents" as target groups.

\section{Figure 8}

Graphical Illustration of the Articles on Special Education and Educational Technologies Since 1970s Indexed in ERIC Database

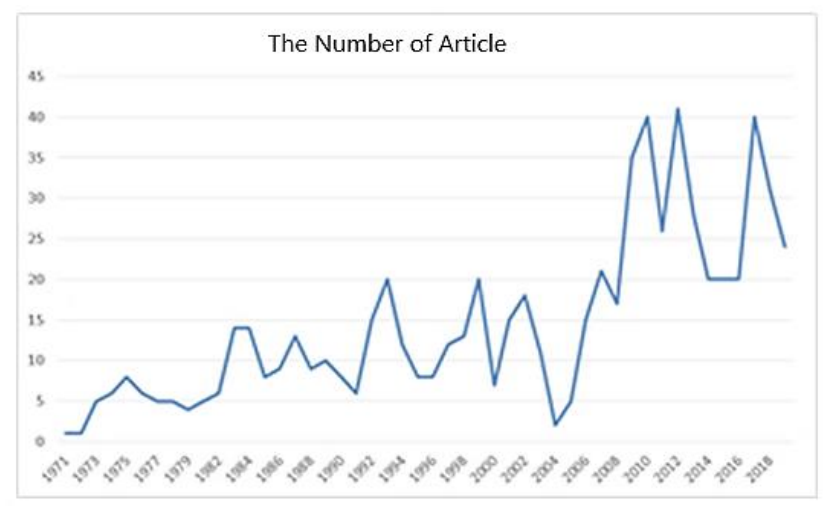

Figure 8 shows the graphical illustration of the articles on special education and educational technologies since the 1970s indexed in the ERIC database. Accordingly, the number of articles on special education and educational technologies has been linearly increasing. There is a significant increase in the number of articles, especially since the 1990 s and 2010 s.

\section{Figure 9}

Analysis of the Abstracts of the Articles on Special Education and Educational Technologies Indexed in ERIC Database
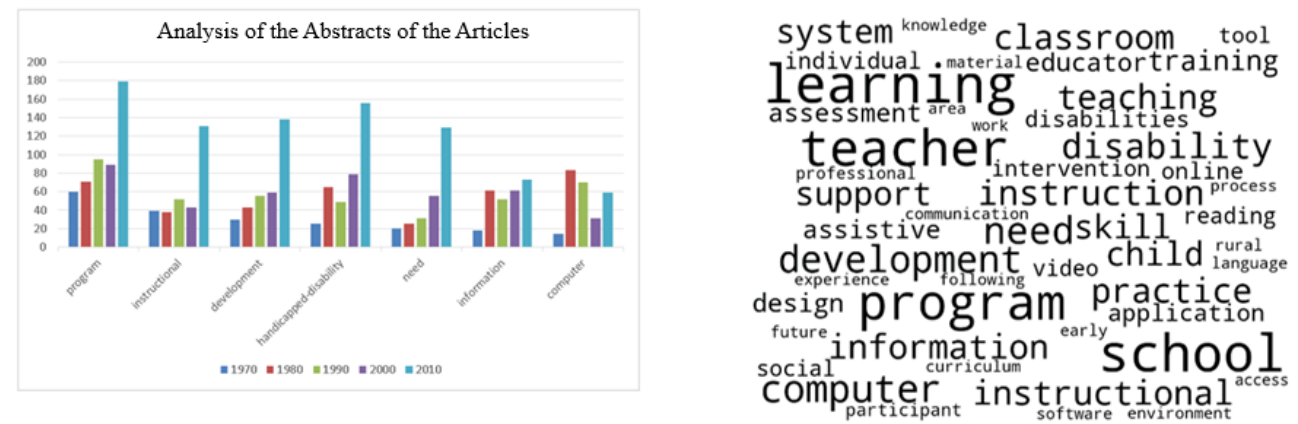
The graphic related to the words found in the abstracts of the articles on special education and educational technologies indexed in the ERIC database is given above in Figure 9. When it is reviewed by years, it is seen that the most frequently used words are "program", "instructional" and "development". Analysis of the total number of words considering all years shows that "learning", "teacher", "school", "program", "development", and "disability" are the most frequently used words.

\section{Figure 10}

Subject Distribution of the Abstracts of the Articles on Special Education and Educational Technologies Indexed in ERIC Database

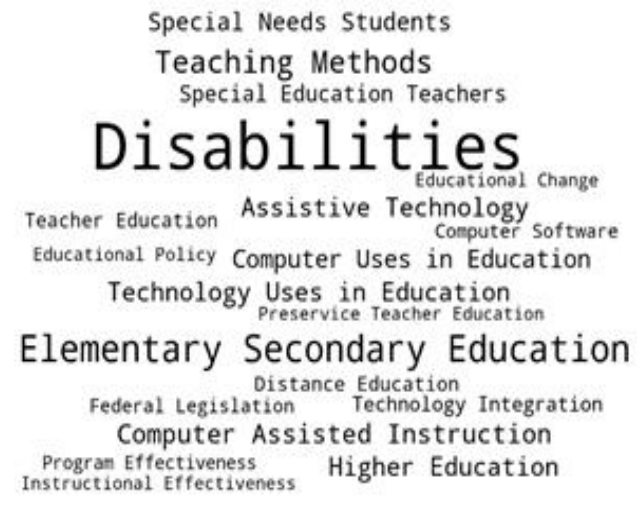

Subject distribution of the articles on special education related to the discipline of educational technologies is given in the figure above. As it can be seen in Figure 10, analysis shows that the studies conducted in the field of special education related to the discipline of educational technologies have focused on "disabilities" $(n=264)$, "elementary secondary education" $(n=229)$, "federal legislation" $(n=154)$, "special needs students" $(n=108)$ and "special education teachers" $(n=105)$. However, "Assistive Technology", "Higher Education", "Uses of Computer in Education", "Students with Special Needs" and "Special Education Teachers" are the subjects primarily studied in the field of special education.

\section{Figure 11}

Target Group Distribution of the Abstracts of the Articles on Special Education and Educational Technologies Indexed in ERIC Database

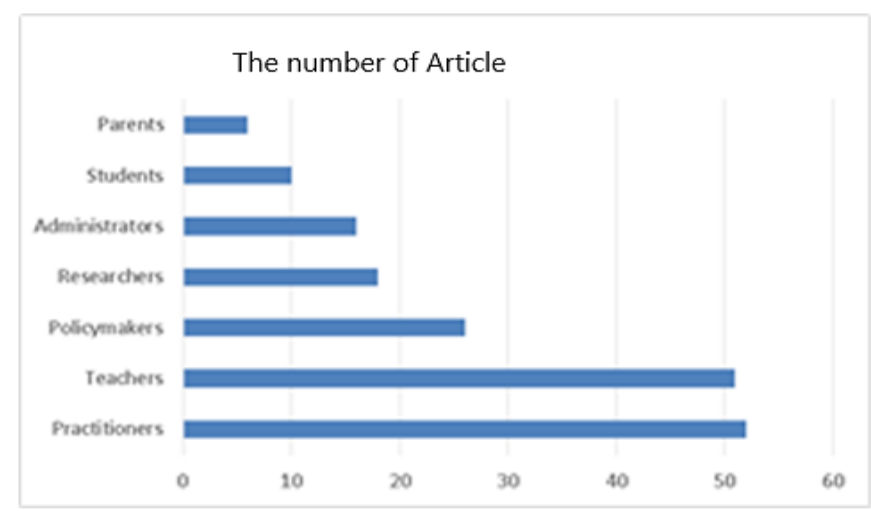

The graphic in Figure 11 shows the target group distribution of the articles on special education related to the discipline of educational technologies. As it is can also be seen in Figure 11, analysis shows that the target group in most of the articles are "practitioners". It is followed by the articles in the literature including "teachers", "policymakers", "researchers" and "administrators" as target groups. 


\section{Figure 12}

Most Researched Educational Technology Subjects in the Field of Special Education

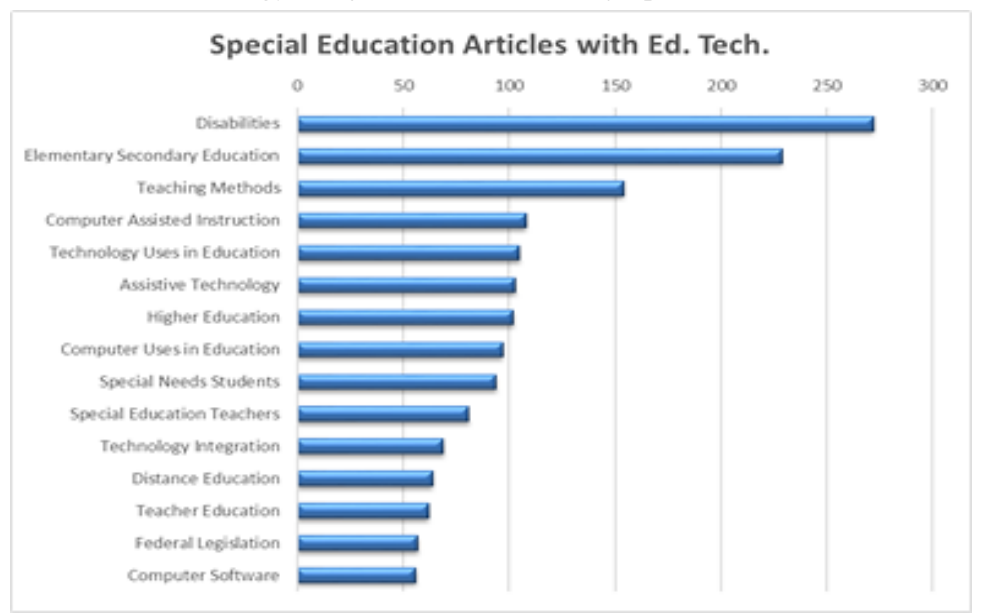

Above is the graphical illustration of the relevance of the studies conducted in the field of special education with the discipline of educational technologies. Figure 12 shows that the most researched subject in special education articles that are supported with the sub-dimensions of educational technologies discipline is "disabilities". However, subjects such as "teaching methods", "use of technology in education", "higher education" and "special needs education" are studied in articles together with educational technologies. There exist subjects that never examine the discipline of educational technologies in the field of special education. The graphic below shows the special education article subjects which were studied many times without benefiting from the discipline of educational technologies.

\section{Figure 13}

Subjects in the Field of Special Education Which Never Studied Educational Technologies

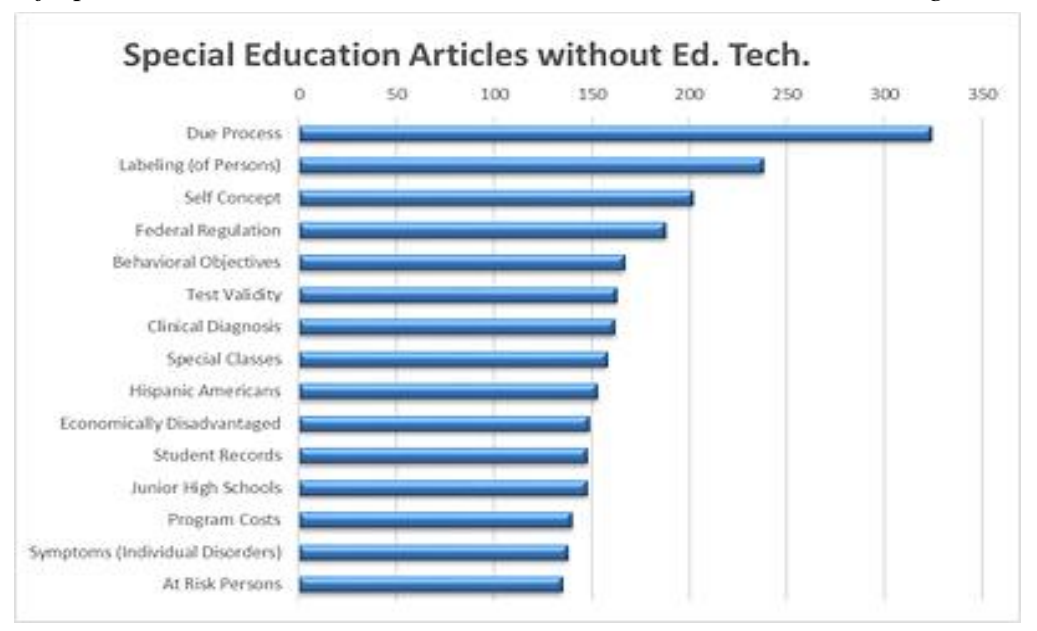

In Figure 13, "due process" has been the most frequently studied subject without benefiting from the discipline of educational technologies from 1960s to the present. The subjects such as "labeling", "self-concept", "federal regulation" and "behavioral objectives" are studied frequently in the field of special education. However, these articles never utilized educational technologies.

\section{Discussion}

In this study, the scientific studies on special education and educational technologies indexed in the ERIC database between 1960-2019 are reviewed with scientometric methods. The findings reveal the general situation regarding the use of educational technologies in the field of special education, and they differ in terms of subject, content, and target audience on a periodical basis. According to these findings, it is seen that the number of articles on special education indexed in the ERIC database has been increasing over the years. However, it is also seen 
that this increase continued until the mid-2000s, but then it slowed down between 2004-2005. Similarly, it is seen that articles on special education and educational technologies are in a linear increase or decrease over the years. It is observed that at the breaking point of the increase, the number of articles on special education fell to as low as 180 from 400. Moreover, during this dramatic decrease, only 2 or 3 articles on special education utilized educational technologies. Despite this, there is a significant increase in number of the articles on special education from 2005 until 2011-2012, but it declined again in 2013. It is seen that there are two fluctuations in the number of studies conducted in the field of special education. The first fluctuation is thought to have been caused by the "no child left behind" movement which emerged in America. This initiative aimed to improve educational achievements and close the achievement gap caused by racial/ethnic differences (Darling-Hammond, 2007). Researchers' planning to carry out studies about the intermediary role of educational technologies to improve achievements is thought to have an impact on the current decline. Similarly, changes made in the diagnostic criteria of Autism Spectrum Disorders may have caused the decline that occurred in 2013. For this reason, the researchers are suggested to study the reasons of this fluctuation in the light of findings obtained in this study.

Analysis of the trends in the abstract parts of the articles on special education indexed in ERIC database shows that the most frequently used word is "school". It is followed by "program", "child", "teacher", "need" and "disability". When this finding is evaluated together with "program", "instructional", "development", "learning", "teacher", "school" and "disability" which are the findings of the articles that include educational technologies in their abstract parts, it can be said that studies from past to present have been focusing on school and there is a consistency in the articles on educational programs. Additionally, it can be said that educational technologies are also included in the program. As a matter of fact, Sani-Bozkurt (2017) remarked that goal, technological tool, software program, method, technique and activities to be used for special education would create a highly effective and interactive learning environment supported with technology for both the learner and the teacher. Şemşit et al. (2016) stated that the program conducted in cooperation with special education institutions (e.g. rehabilitation centers) aimed to facilitate the transition of the students with special needs from school to the labor market. As an example of this, they stated that the Ministry of Social Affairs and Employment in Holland supports the municipalities to implement programs for the individuals with special needs to participate in the labor market. The fact that schools give real life skills with the help of technology supported programs in special education is very exciting. However, it is possible to say that the trends with real life skills related to children and teachers have an extensive coverage in the study. The softwares used in the study are thought to have led to this finding. It is stated that, under the guidance of teachers, computer softwares may improve language and communication skills of the children with speech and language disorders and those with autism spectrum disorder (Heward, 2013) to express their own requests and needs and to make sentences (Sani-Bozkurt, 2017). The most important finding obtained from the analysis of the abstract texts is that the word "handicapped", which was replaced later with "disability", was included in the abstract parts of studies from the 1980s until the early 1990s. Preferring to use the term "disabled" instead of "handicapped" is thought to have caused this shift in the literature. As a matter of fact, the term "handicapped" refers to having an impediment, defect while the term "disabled" refers to having a missing body part (Turkish Language Society, 1932). However, it should always be kept in mind that everyone can potentially become disabled and governments have made amendments in the law regarding the use of this term. For instance, with the Act 6462 which came into effect in 2013, the Turkish Republic legislated the use of the "disability" term instead of handicapped (unfit for military service). Likewise, in the International Classification of Impairments, Disabilities and Handicaps (ICIDH) manual published by the World Health Organization (WHO) (1980), impairment is defined as any abnormality of the psychological, physiological, or anatomical structure of function while disability is defined as any restriction or lack (resulting from an impairment) of ability to perform an activity. A handicap is a disadvantage for an individual, resulting from an impairment or a disability, that limits or prevents the fulfillment of a role that is typical for that individual. Similarly, it is seen that the high number of studies conducted on vocational training in the field of special education in the past has substantially declined. Binici and Ar1 (2004) highlight the importance of vocational training and point to competition and the particular importance of professional qualifications in the labor market. They also point to the need to create a competitive environment required for being employed. For this reason, it may be necessary to carry out further studies to review whether the vocational training in special education is of high quality and competitive. When articles on special education are reviewed in terms of subject, it is seen that "Disabilities" stands out as the most studied subject while it is followed by "Secondary Education", "Federal Legislation", "Students with Special Needs", "Special Education Teachers", "Teaching Methods", "Mainstreaming", "Learning Disabilities" and "Educational Legislation". When this finding is evaluated together with "Disabilities", "Elementary Secondary Education", "Teaching Methods", "Computer Assisted Instruction", "Technology Uses in Education", "Assistive 
Technology", "Higher Education", "Uses of Computer in Education", "Students with Special Needs" and "Special Education Teachers", it becomes evident that computer is used as an assistive and only educational technology in special education. Although "assistive technology" is researched in the studies, it is clearly seen that educational technology refers to "computer" in these studies. In their study, Özak and Avcioğlu (2007) suggest that simultaneous clues presented over computers are effective in teaching reading skills to students with intellectual disabilities. However, there are many other developments occurred in the historical development of educational technologies, such as mobile learning, augmented reality, and virtual reality. It is stated that technologies such as mobile applications, smart personal assistants, and augmented reality applications can be used as assistive technologies in special education (Sani-Bozkurt, 2017), implementation-oriented studies in recent years are very limited (Karanfiller et al., 2017; Subakan \& Koç, 2019; Yaman et al., 2016). As a matter of fact, ERIC database is an educational index, the findings reached in this study are expected to enrich existing literature and contribute to presenting the big picture. In the studies carried out from past to the present, it is seen that not many educational technologies are utilized in the field of special education other than "computer" while the number of studies including "mobile technology" "augmented reality" and "virtual reality" is not enough. Additionally, studies on augmented reality and virtual reality do not yield useful results with the "assistive technology" subject.

Analysis of the articles on special education in terms of target group variable shows that the target group in most of the articles is "practitioners" which is followed by "teachers", "policymakers", "administrators" and "parents". A similar situation is present also in the articles in which educational technologies are studied together. The different point here is "researchers" that are among the target groups of articles and use educational technologies in the field of special education. Relying on the findings, it is observed that pre-service teachers should also be studied as a target group in the studies. Additionally, studies using educational technologies in the field of special education should be carried out in a way to include "parents" as a target group. Sani-Bozkurt (2017) states that for an efficient education, the expert who is going to use the assistive technology, parents, and other relevant experts should be deciding together in the process of planning. Cavkaytar (1999) remarks that studies on parents' active involvement in their children's education make huge contributions to families, children and educational processes.

When the articles that studied educational technologies together with the field of special education are analyzed, it is seen that "disabilities" is the most studied subject. According to Öztabak (2017), the concept of disability is a more general concept that includes the concepts of disorder and disability. In addition to this explanation, the concept of disability does not only concern the individual, because a disabled person constantly encounters other obstacles in the social environment (at school, on the streets, in the buildings of public institutions, cinemas, shopping centers, sports fields, etc.). Accordingly, the disability is a social problem. Stigma (1968) stated that the physical characteristics of the individual do not prevent her/his from being a part of the society s/he lives in, but the meaning and labeling attributed to the disability is what creates this situation. Based on these meanings of the concepts, The statements of Siebers (2001) reveal that social attitudes, values, and institutions in the sociocultural structure are much more effective than biological facts in determining the reality of the body are in parallel with the trends observed in findings.

The combination of disability findings is followed by articles on "teaching methods", "uses of technology in education", "higher education" and "special needs education" which are studied together with educational technologies. Even though there exist special education studies focusing on the use of educational technologies, there are still subjects in special education for which the discipline of educational technologies has not been used yet. For example, studies on "due process" subject, which has been frequently studied in special education since the 1960s, have not dealt with the discipline of educational technologies. Although there are nearly 380 studies on "due process", it is seen that educational technologies were not used in any of these studies. Although subjects such as "labeling", "self-concept", "federal regulation" and "behavioral objectives" have been studied frequently in the field of special education, it is seen that educational technologies have not been used in these studies. However, the "due process" subject can be studied with technological development subject. At this point, examining these frequently studied subjects in special education together with educational technologies is necessary.

\section{Limitations and Recommendations}

This study is limited to the studies on educational technologies and special education indexed in ERIC database between 1960-2019. In the light of the findings obtained in this study, which reviews the studies that focus on the subjects of special education and educational technologies, the future studies are suggested to utilize 
educational technologies when studying frequently preferred subjects. On the basis of this suggestion, the concept of educational technologies should not be perceived as it is about only computers. The teaching programs and curricula are recommended to be updated and structured considering the historical development of educational technologies. Technologies currently used in the educational environments should be integrated into educational process after necessary adaptations are made in the light of newly emerging technologies. Especially considering the findings on most researched educational technology subjects in the field of special education, it is recommended that individualized education plans (IEP) could be incorporated with educational technologies and teaching methods, rather than single usage of computers or assistive technologies. Considering the development in the field of education, instructors, researchers, and practitioners might have collaboration with the expert on the field of Computer Education and Instructional Technology (CEIT) to integrate the most effective educational technology and teaching method based on the developmental characteristics of students with special needs. Families have a great potential to give meaningful support in this process. In this respect, the educational environments enriched with educational technologies for those with special needs should not be limited to school only. The educational environments aiming to give those with special needs the necessary skills and qualifications should be designed and arranged with the support of families. Future studies are also suggested to involve preservice teachers as a target group as well as families. Educational technologists should cooperate more with special education experts, pre-service special education teachers, academics, program developers, and administrators to design and develop educational environments supported with technology and cooperative implementations in order to meet needs and expectations. Researchers are also recommended to investigate the reasons of the fluctuations in depth which are regarded as a highly significant finding obtained in this study. Finally, future studies and researchers are recommended to review educational technologies with respect to various disciplines and to examine the periods in a more detailed way as it is considered important to reveal trends in teaching environments and the learning process.

\section{Authors' Contributions}

The process of obtaining and analyzing big data in the study and the idea and method part of the study belong to third author. The transformation and interpretation of the findings obtained in the study was carried out by second author. Other parts of the study are introduction, literature, conclusion, discussion and limitations completed by first author. 


\section{References}

Alnahdi, G. (2014). Assistive technology in special education and the universal design for learning. TOJET: The Turkish Online Journal of Educational Technology, 13(2), 18-23. https://files.eric.ed.gov/fulltext/EJ1022880.pdf

Aslan, C. (2018). Özel eğitim öğretmenlerinin yardımcı teknolojilere yönelik tutumları [Attitudes of special education teachers towards assistive technology]. Eğitim Teknolojisi Kuram ve Uygulama, 8(1), 102-120. https://doi.org/10.17943/etku.319972

Bahceci, B. (2019). Özel eğitim alanında çalışan öğretmenlerin yardımcı teknolojilere yönelik tutumlarının ve bireysel yenilikçilik düzeylerinin incelenmesi [To examine attitudes of teachers working in the field of special education towards assistive technologies and individual innovation levels] (Tez Numaras1: 554261) [Yüksek lisans tezi, Necmettin Erbakan Üniversitesi]. Yükseköğretim Kurulu Ulusal Tez Merkezi.

Binici, H., \& Arı, N. (2004). Mesleki ve teknik eğitimde arayışlar [Seeking new perspectives in technical and vocational education]. Gazi Üniversitesi Gazi Eğitim Fakültesi Dergisi, 24(3), 383-396. https://dergipark.org.tr/en/download/article-file/77312

Bird, S., Loper, E., \& Klein, E. (2009). Natural language processing with python. O’Reilly Media Inc.

Caffarella, E. P. (1991). Doctoral research in instructional design and technology: A directory of dissertations 1987-1988. Association for Educational Communications and Technology.

Caffarella, E. P. (1999). The major themes and trends in doctorial dissertation research in educational technology from 1977 through 1998. Educational Media and Technology Yearbook, 25, 14-25. https://files.eric.ed.gov/fulltext/ED436178.pdf

Caffarella, E. P. (2000). Doctoral dissertation research in educational technology: The themes and trends from 1977 through 1998. In R. M. Branch \& M. A. Fitzgerald (Eds.), Educational media and technology yearbook (pp. 483-490). Unlimited. https://www.researchgate.net/publication/234648060_Doctoral_Dissertation_Research_in_Educational_ Technology_The_Themes_and_Trends_from_1977_through_1998

Caffarella, E. P., \& Sachs, S. G. (1988). Doctoral research in instructional design and technology: A directory of dissertations 1977-1986. Association for Educational Communications and Technology. https://files.eric.ed.gov/fulltext/ED307852.pdf

Cavkaytar, A. (1999). Zihin engellilere özbakım ve ev içi becerilerinin öğretiminde bir aile eğitimi programının etkililiği [The effectivenness of a parent training program for teaching self-care and domestic skills to mentally handicapped children]. Ankara Üniversitesi Ĕ̈itim Bilimleri Fakültesi Özel Eğitim Dergisi, 2(3), 40-50. https://dergipark.org.tr/en/download/article-file/159249

Chen, C. P., \& Zhang, C. Y. (2014). Data-intensive applications, challenges, techniques and technologies: A survey on big data. Information Sciences, 275, 314-347. https://doi.org/10.1016/j.ins.2014.01.015

Chen, M., Mao, S., \& Liu, Y. (2014). Big data: A survey. Mobile Networks and Applications, 19, 171-209. https://doi.org/10.1007/s11036-013-0489-0

Costa, F. A. (2007). Educational technologies: Analysis of master dissertation carried out in Portugal. Educational Sciences Journal, 3, 7-24. https://repositorio.ul.pt/handle/10451/7029

Coşkun, İ., Dündar, Ş., \& Parlak, C. (2014). Türkiye'de özel eğitim alanında yapılmış lisansüstü tezlerin çeşitli değişkenler açısından incelenmesi (2008-2013) [The analysis of the postgraduate thesis written on special education in terms of various criteria in Turkey (2008-2013)]. Ege Eğitim Dergisi, 15(2), 375-396. https://dergipark.org.tr/tr/pub/egeefd/issue/4926/67414

Coşkun, T. K., \& Alper, A. (2019). Usage of digital learning material in special education. Ankara University Faculty of Educational Sciences Journal of Special Education, 20(1), 119-142. https://doi.org/10.21565/ozelegitimdergisi.423349 
Cumming, T. M., \& Draper-Rodríguez, C. (2017). A meta-analysis of mobile technology supporting individuals with disabilities. The Journal of Special Education, 51(3), 164-176. https://doi.org/10.1177/0022466917713983

Çal, C. C. (2011). Işsitme engelliler için uzaktan eğitim amaçlı, web tabanlı bir arayüz tasarımı ve uygulaması [A web based interface design and application for remote education of deaf people] (Tez Numaras1: 285436) [Yüksek lisans tezi, Trakya Üniversitesi]. Yükseköğretim Kurulu Ulusal Tez Merkezi.

Darling-Hammond, L. (2007). Race, inequality and educational accountability: The irony of 'No Child Left Behind'. Race Ethnicity and Education, 10(3), 245-260. https://doi.org/10.1080/13613320701503207

Davi, A., Haughton, D., Nasr, N., Shah, G., Skaletsky, M., \& Spack, R. (2005). A review of two text-mining packages: SAS TextMining and WordStat. The American Statistician, 59(1), 89-103. https://doi.org/10.1198/000313005X22987

Doğan, N. (2010). Bilgisayar destekli istatistik öğretiminin başarıya ve istatistiğe karşı tutuma etkisi [The effect of computer-assisted statistics instruction on achievement and attitudes toward statistics]. Eğitim ve Bilim, 34(154), 3-16. http://egitimvebilim.ted.org.tr/index.php/EB/article/view/543/32

Erdoğmuş, F. U., \& Çağıltay, K. (2009, 11-13 Şubat). Türkiye'de eğitim teknolojileri alanında yapılan master ve doktora tezlerinde genel eğilimler [General trends in master's and doctoral theses in the field of educational technologies in Turkey] [Sözlü bildiri]. Akademik Bilişim'09 - XI. Akademik Bilişim Konferansı. Harran Üniversitesi, Şanlıurfa, Türkiye.

Fan, J., Han, F., \& Liu, H. (2014). Challenges of big data analysis. National Science Review, 1(2), 293-314. https://doi.org/10.1093/nsr/nwt032

Fazlıoğulları, O., \& Kurul, N. (2012). Türkiye'deki eğitim bilimleri doktora tezlerinin karakteristikleri [The characteristics of doctoral dissertations of educational sciences in Turkey]. Mehmet Akif Ersoy Üniversitesi Ĕ̆itim Fakültesi Dergisi, 24(1), 43-75. https://dergipark.org.tr/en/download/article$\underline{\text { file/181394 }}$

Feinerer, I., Hornik, K., \& Meyer, D. (2008). Text mining infrastructure in R. Journal of Statistical Software, 25(5), 1-54. http://dx.doi.org/10.18637/jss.v025.i05

Gandomi, A., \& Haider, M. (2015). Beyond the hype: Big data concepts, methods, and analytics. International Journal of Information Management, 35(2), 137-144. https://doi.org/10.1016/j.ijinfomgt.2014.10.007

Gökoğlu, S., Erdemir, T., Öztürk, M., \& Çakıroğlu, Ü. (2014, 18-20 Eylül). BÖTE sempozyumlarında sunulan çalışmalardaki eğilimler: İçerik analizi çalışması [Trends in the studies presented at ICITIS: Content analysis study] [Sözlü bildiri]. 8. Uluslararası Bilgisayar ve Öğretim Teknolojileri Sempozyumu, Trakya Üniversitesi, Edirne, Türkiye.

Göktaş, Y., Küçük, S., Aydemir, M., Telli, E., Arpacık, Ö., Yıldırım, G., \& Reisoğlu, İ. (2012). Educational technology research trends in Turkey: A content analysis of the 2000-2009 decade. Educational Sciences: Theory \& Practice, 12(1), 177-199. https://files.eric.ed.gov/fulltext/EJ978439.pdf

Gülbahar, Y., \& Alper, A. (2009). Öğretim teknolojileri alanında yapılan araştırmalar konusunda bir içerik analizi [A content analysis of the studies in instructional technologies area]. Ankara Üniversitesi Ĕ̈itim Bilimleri Fakültesi Dergisi, 42(2), 93-112. https://doi.org/10.1501/Egifak_0000001178

He, W., Zha, S., \& Li, L. (2013). Social media competitive analysis and text mining: A case study in the pizza industry. International Journal of Information Management, 33(3), 464-472. https://doi.org/10.1016/j.ijinfomgt.2013.01.001

Heward, W. L. (2013). Exceptional children: An introduction to special education (10th ed.). Pearson.

İşbulan, O., Hamutoğlu, N. B., \& Kıyıcı, M. (2021). Yükseköğretim alanında yapılan ulusal ve uluslararası çalışmalardaki eğilimlerin büyük veri ve veri madenciliği ile incelenmesi: 1965-2019 [Investigation of trends in national and international studies in higher education by means of big data and data mining: 1965-2019]. Yükseköğretim Dergisi, 11(2), 276-296. https://doi.org/10.2399/yod.20.735528 
İşman, A. (2011). Öğretim teknolojileri ve materyal tasarımı [Instructional technologies and material design] (4. baskı). Pegem Akademi.

Karanfiller, T., Göksu, H., \& Yurtkan, K. (2017). A mobile application design for students who need special education. Education and Science, 42(192), 367-381. https://doi.org/10.15390/EB.2017.7146

Karasar, N. (2010). Bilimsel araştırma yöntemi [Scientific research method] (21. bask1). Nobel.

Keser, H., \& Özdemir, O. (2017). İşitme yetersizliği olan öğrencilerin eğitimlerinde bilgisayar destekli kelime öğretim materyali kullanımının incelenmesi [Examination of the use of computer aided word teaching material for the education of students with hearing 1mpairment]. Ankara Üniversitesi Eğitim Bilimleri Fakültesi Özel Eğitim Dergisi, 19(1), 29-53. https://doi.org/10.21565/ozelegitimdergisi.300290

Kışla, T. (2008). Özel eğitim öğretmenlerinin bilgisayar tutumlarının incelenmesi [Investigating computer attitudes of special education teachers]. Ege Eğitim Dergisi, 9(2), 127-153. https://dergipark.org.tr/en/download/article-file/57049

Klein, D. J. (1997). ETR\&D-development: An analysis of content and survey of future direction. Educational Technology Research and Development, 45(3), 57-62. https://doi.org/10.1007/BF02299729

Ma, Y. (2000, February 16-20). Research in educational communications and technology at the University of Wisconsin: A study of dissertation completed since the inception of the program [Paper presentation]. 22nd National Convention of the Association for Educational Communications and Technology, Long Beach, California, United States.

McKinney, W. (2010, June 28-July 3). Data structures for statistical computing in python [Paper presentation]. Proceedings of the 9th Python in Science Conference, Austin, Texas, United States.

Öngöz, S., \& Özer-Şanal, S. (2017). Özel eğitimde dijital kitap kullanımı. H. F. Odabaşı, B. Akkoyunlu, \& A. İşman (Eds.), Ĕ̈itim teknolojileri okumaları [Educational technology readings] içinde (ss. 330-340). Pegem Akademi Yayıncılık

Özak, H., \& Avcioğlu, H. (2007). Zihinsel yetersizliği olan öğrencilere okuma becerilerinin öğretiminde bilgisayar aracılığıyla sunulan eş zamanlı ipucuyla öğretimin etkililiği [The effects of simultaneous prompting presented via computer on the reading skills of children with intellectual disability]. Abant Izzet Baysal Üniversitesi Eğitim Fakültesi Dergisi, 12(1), 33-50. https://dergipark.org.tr/tr/download/articlefile/16814

Öztabak, M. Ü. (2017). Engelli bireylerin yaşamdan beklentilerinin incelenmesi [Investigation of life expectations of disabled persons]. FSM İlmî Araştırmalar Insan ve Toplum Bilimleri Dergisi, 9, 355-375. https://dergipark.org.tr/en/download/article-file/317613

Ross, S. M., Morrison, G. R., \& Lowther, D. L. (2010). Educational technology research past and present: Balancing rigor and relevance to impact school learning. Contemporary Educational Technology, 1(1), 17-35. https://doi.org/10.30935/cedtech/5959

Sani-Bozkurt, S. (2017). Özel eğitimde dijital destek: Yardımcı teknolojiler [Digital support in special education: assistive technologies]. Açıö̈ğretim Uygulamaları ve Araştırmaları Dergisi, 3(2), 37-60. https://dergipark.org.tr/en/download/article-file/403817

Schwandt, T. A. (1990). Paths to inquiry in the social disciplines: Scientific, constructivist, and critical theory methodologies. In E. G. Guba (Ed.), The paradigm dialog (pp. 258-76). Sage Publications.

Şemşit, S., Uçar, A., \& Yüksel, M. A. (2016). Avrupa Birliği politikalari perspektifinden Türkiye’de belediyelerin sunduğu engelli hizmetleri [Disability implementations of the municipalities in Turkey in perspective of European Union disability policies]. Dumlupınar Üniversitesi Sosyal Bilimler Dergisi, Özel Sayl, 205223. https://dergipark.org.tr/en/download/article-file/354788

Siebers, T. (2001). Disability in theory: From social constructionism to the new realism of the body. American Literary History, 13(4), 737-754. https://www.jstor.org/stable/pdf/3054594.pdf 
Şimşek, A., Özdamar, N., Becit, G., Kılıçer, K., Akbulut, Y., \& Yıldırım, Y. (2008). Türkiye'deki eğitim teknolojisi araştırmalarında güncel eğilimler [Current trends in educational technology research in Turkey]. Selçuk Üniversitesi Sosyal Bilimler Enstitüsü Dergisi, 19, 439-458. https://dergipark.org.tr/en/download/article-file/1723975

Şimşek, A., Özdamar, N., Uysal, Ö., Kobak, K., Berk, C., Kılıçer, T., \& Çiğdem, H. (2009). İki binli yıllarda Türkiye'deki eğitim teknolojisi araştırmalarında gözlenen eğilimler [Current trends in educational technology research in Turkey in the new millennium]. Kuram ve Uygulamada Ĕgitim Bilimleri, 9(2), 941-966. https://www.researchgate.net/publication/274960172_Iki_Binli_Yillarda_Turkiye'deki_Egitim _Teknolojisi_Arastirmalarinda_Gozlenen_Egilimler

Stigma, E. G. (1968). Notes on the management of spoiled identity. Prentice Hall.

Subakan, Y., \& Koç, M. (2019). Özel eğitim gereksinimli bireylerin gelişim ve eğitimlerinde kullanılan mobil cihazlar ve yazılımlar [Mobile technologies used for the development and education of individuals with special educational needs]. Bilim Eğitim Sanat ve Teknoloji Dergisi, 3(2), 51-61. https://dergipark.org.tr/en/download/article-file/586372

Türk Dil Kurumu [Turkish Language Society]. (1932). Türk Dil Kurumu sözlükleri [Turkish Language Society dictionaries]. Retrieved May 12, 2020, from https://sozluk.gov.tr/

Tosuntaş, Ş. B., Emirtekin, E., \& Süral, İ. (2019). Eğitim ve öğretim teknolojileri konusunda yapılan tezlerin incelenmesi (2013-2018) [Examination of theses on educational and instructional technologies (20132018)]. Yüksekögretim ve Bilim Dergisi, 9(2), 277-286. https://dergipark.org.tr/en/download/articlefile/1712199

Tsantis, L., \& Castellani, J. (2001). Enhancing learning environments through solution-based knowledge discovery tools: Forecasting for self-perpetuating systemic reform. Journal of Special Education Technology, 16(4), 39-52. https://doi.org/10.1177/016264340101600406

Üstündağ, D. A. (2013). Türkiye'de bilgisayar ve öğretim teknolojileri eğitimi alanındaki yüksek lisans tezlerinin araştırma eğilimleri [Research trends of the master of science theses in the field of computer education and instructional technologies in Turkey]. Eğitim Teknolojisi Kuram ve Uygulama, 3(1), 55-71. https://dergipark.org.tr/en/download/article-file/71813

Wallerstein, I. (2003). Yeni bir sosyal bilim için [For a new social science] (E. Abadoğlu, Çev.). Aram Yayıncılık.

Yaman, F., Dönmez, O., Avc1, E., \& Yurdakul, I. K. (2016). İşitme engelli öğrencilerin okuma-yazma eğitiminde mobil uygulama kullanımı [Integrating mobile applications into hearing impaired children's literacy instuction]. Eğitim ve Bilim, 41(188), 153-174. https://dx.doi.org/10.15390/EB.2016.6687 


\section{Ankara Üniversitesi Eğitim Bilimleri Fakültesi Özel Eğitim Dergisi}

2022, 23(4), 751-773
ARAȘTIRMA

Gönderim Tarihi: 04.01.20

Kabul Tarihi: 02.01.22

Erken Görünüm: 22.02.22

\section{0-2019 Yılları Arasında Özel Eğitimdeki Başlıca Eğilimlerin Eğitim Teknolojileri Çerçevesinde İncelenmesi}

\author{
Nazire Burçin Hamutoğlu $(\mathbb{D} 1$
}

\author{
Onur İșbulan $\mathbb{D}^{2}$
}

Mübin Kıyıcı (D)3

$\ddot{O} \mathbf{z}$

Giriş: Ulaşım, sağlık, iletişim ve eğitim alanlarındaki baş döndürücü teknolojik gelişmeler, geçmişten günümüze hayatımızı kolaylaştırmaya devam etmektedir. Özel gereksinimli öğrencilerin gelişimsel ve mesleki özellikleri göz önünde bulundurularak; eğitim teknolojilerinin öğrenme ve öğretme süreçlerini zenginleştirmede yeterlik kazandırma açısından çok önemli bir yere sahip olduğu düşünülmektedir.

Yöntem: Bu çalışmada 1960-2019 yılları arasında ERIC veri tabanında özel eğitim ve eğitim teknolojileri konusunu içeren 22049 çalışma "Özel Eğitim" ve "Eğitim Teknolojisi” etiketleri kullanılarak bilimetrik yöntemler ile incelenmiştir. İçerik analizi kullanılarak gerçekleştirilen bu çalışma amaçsal açıdan tanımlayıcı/betimleyici nitelikte bir araştırmadır.

Bulgular: Çalı̧̧manın en değerli bulguları arasında 1980'ler ve 1990'ların başına kadar "handicapped" kelimesinin özetlerde yer alması, ancak daha sonra bu kelimenin yerini "disability" kelimesine bırakması olduğu söylenebilir. Bununla birlikte özel eğitimde eğitim teknolojileri olarak bilgisayarın sıklıkla kullanılması çalışmanın dikkat çeken bir diğer bulgusudur. Elde edilen sonuçlar da düşünüldüğünde "okul" ların teknoloji destekli programlar ile özel eğitim alanı için gerçek yaşam becerilerinin kazandırıldığı bir ortam olması fikri oldukça heyecan vericidir. Bununla birlikte, çalışmada çocuk ve öğretmen ile ilgili gerçek yaşam becerilerinin olduğu trendlerin de önemli bir yer tuttuğunu söylemek mümkündür. Bu sonucun elde edilmesinde kullanılan bilgisayar yazılımlarının etkisinin olduğu düşünülmektedir.

Tartışma: Elde edilen bulgulara dayalı olarak gelecek araştırmacılara, müfredat programlarını bu doğrultuda yenilemeleri ve teknolojik gelişmelerden yararlanarak düzenlemeleri önerilmektedir. Bununla birlikte gelecek çalışmalarda hedef kitlenin sadece aileleri değil öğretmen adaylarını da kapsayacak şekilde planlanması önerilmektedir.

Anahtar sözcükler: Metin madenciliği, eğitim, değerlendirme, bibliyometrik analiz, özel eğitim, teknoloji.

Atıf için: Hamutoğlu, N. B., İşbulan, O., \& Kıyıcı, M. (2022). 1960-2019 yılları arasında özel eğitimdeki başlıca eğilimlerin eğitim teknolojileri çerçevesinde incelenmesi. Ankara Üniversitesi Eğitim Bilimleri Fakültesi Özel Eğitim Dergisi, 23(4), 751-773. https:// doi.org/10.21565/ozelegitimdergisi.835696

\footnotetext{
${ }^{1}$ Sorumlu Yazar: Öğr. Gör. Dr., Eskişehir Teknik Üniversitesi, E-posta: nbhamutoglu @ eskisehir.edu.tr, https://orcid.org/00000003-0941-9070

${ }^{2}$ Dr. Öğr. Üyesi, Sakarya Üniversitesi, E-posta: oisbulan@ @akarya.edu.tr, https://orcid.org/0000-0001-5326-071X

${ }^{3}$ Prof. Dr., Sakarya Üniversitesi, E-posta: mkiyici@ sakarya.edu.tr, https://orcid.org/0000-0001-9458-7831
} 


\section{Giriş}

Eğitim teknolojilerinde meydana gelen gelişmeler pek çok araştırmacının ilgi odağı olmuştur ve olmaya da devam etmektedir. Alanyazında içerik analizi yöntemi ile çalışmaların biçim, içerik ve yöntem boyutlarıyla ele alındığı gibi konu, hedef kitle ve tercih edilen araştırma modeli, verilerin elde edilme ve analiz edilme şekli olarak da sinıflandırılmaktadır (Akça-Üstündağ, 2013; Cafferalla, 1999; Erdoğmuş \& Çağıltay, 2009; Gökoğlu vd., 2014; Göktaş vd., 2012; Gülbahar \& Alper; 2009; Ma, 2000; Şimşek vd., 2008; Şimşek vd., 2009; Tosuntaş vd., 2019). Bununla birlikte içerik analizi ile incelenen çalışmaların doktora ve yüksek lisans tezleri ile makaleler olduğu görülmektedir. Türkiye'de yapılan çalışmalarda elde edilen bulgular eğitim teknolojileri alanını kapsamaktan ziyade daha çok spesifik bir konuya odaklanıldığını (Gülbahar \& Alper, 2009; Şimşek vd., 2008; Şimşek vd., 2009) ve araştırma modeli olarak daha çok nicel çalışmaların yoğunlukta olduğu konusunda ortak görüsşe sahiptir (Akça-Üstündağ, 2013; Gülbahar \& Alper, 2009; Şimşek vd., 2008; Şimşek vd., 2009). Bununla birlikte yapılan çalışmalarda eğitim teknolojileri alanındaki eğilimlerin zamanla değiştiğini rapor eden çalışmalar da alanyazında mevcuttur (Akça-Üstündağ, 2013; Cafferalla, 1999). Bu noktada yapılan çalışmalarda tematik eğilimlerin ve araştırma yöntemlerinin betimlendiği görülse de yöntemsel ve tematik çeşitliliğin sınırlı olduğu görülmektedir. Bu çalışmada 1960-2019 yılları arasında ERIC veri tabanında özel eğitim ve eğitim teknolojileri konusunu içeren çalışmalar bilimetrik yöntemler ile incelenmiştir. İçerik analizi kullanılarak gerçekleştirilen bu çalışma amaçsal açıdan tanımlayıcı/betimleyici nitelikte bir araştırma olup, elde edilen sonuçlar ERIC veri tabanında yer alan dergilerin başlıkları ve özet bölümlerinde yer alan kelimeler içerik analizi tekniklerine uygun olarak kategorilendirilerek yüzde ve frekans analizi tekniklerine dayalı olarak kelime bulutları oluşturularak sunulmuştur.

\section{Yöntem}

$\mathrm{Bu}$ çalı̧̧ma içerik analizi kullanılarak gerçekleştirilmiş olup; amaçsal açıdan tanımlayıcı/betimleyici nitelikte bir araştırma olup küresel düzlemde bilimetrik bakış açısı ile incelenmektedir. Ayrıca çalışma eğitim teknolojileri ile özel eğitim alanındaki gelişmelerin ilgisi de birlikte ele almaktadır. Araştırmada çalışma materyali olarak belirlenen ERIC veri tabanında yer alan dergilerin başlıkları ve özet bölümlerinde yer alan kelimeler içerik analizi tekniklerine uygun olarak kategorilendirilerek yüzde ve frekans analizi tekniklerine dayalı olarak kelime bulutları oluşturularak sunulmuştur.

\section{Araştırma Süreci}

Günümüzde veri toplama ve büyük veriyi analiz etme olanaklarının artışı ile birlikte büyük veriye doğru olan ilgi her geçen gün artmaktadır. Büyük veri analiz yöntemlerinden bir tanesi de veri madenciliği yöntemidir. Veri madenciliği yapılandırılmamış ve büyük miktardaki metin veri kaynaklarından anlamlı bilgiler elde etmek, yeni örüntüler çıkarmak ve veriyi bilgiye dönüştürmek üzere gerçekleştirilen bir analiz yöntemidir (He vd., 2013; Tsantis \& Castellani, 2001). Veri madenciliği standart yöntemleri arasında metin sinıflandırma (text classification), metin kümeleme (text clustering), ontoloji ve taksonomi oluşturma (ontology and taxonomy creation), belge özetleme (document summarization) ve gizil bütünce analizi (latent corpus analysis) bulunmaktadır (Feinerer vd., 2008). Büyük veri analizi ya da veri madenciliği süreçlerinde tek bir doğru bulunmamaktadır. Çünkü veri ile ilgili bilgiler farklı formatlarda saklanmaktadır. Büyük veri uygulamalarının yaygınlaşması ile birlikte veri, konvansiyonel metin yerine XML veya CSV dosyaları ile iletilen ya da API'ler yardımıyla sorgulanabilir meta data olarak saklanır bir duruma gelmiştir (Feinerer vd., 2008). Belirtilen formatlar ile hizmete sunulan büyük verinin farklı paket programlar ile otomatik olarak işlenerek analiz yapılabileceği gibi araştırmacılar tarafından geliştirilecek programlar ile de analiz edilip işlenebilmektedir. Araş̧ırmacı ister paket program kullansın, isterse kendi programını geliştirsin nitel veri analizinde veri madenciliği sıkça kullanılan bir tekniktir. Veri madenciliğinin amaçları arasında büyük veri setinden anahtar elementleri çıkarma ve bu elementler arasındaki ilişkileri tespit ederek özetleme yer almaktadır (Davi vd., 2005). Fan ve diğerleri (2014) büyük veri ve veri madenciliği süreçleri ile birlikte birçok olanağın ortaya çıkmasının yanı sıra araştırmacılara birçok zorluk getireceğini da belirtmektedirler. Veri madenciliği alan yazını araştırmacılara adım adım izleyecekleri bir şablondan çok genel uyacakları kurallar dizilerini geliştirmiştir. Bu süreçlerden dolayı da veri madenciliği süreçlerinde paket programlardan çok araştırmacılar tarafindan geliştirilen programlar/scriptler kullanılır hale gelmiştir. Veri madenciliği süreçlerinde yol haritası olarak izlenebilecek iki farklı teknikten bahsedilebilir.

Çalışma kapsamında ERIC veri tabanında indekslenmiş olan makalelerin farklı değişkenler açısından incelenmesi hedeflenmiş̧tir. Bu amacı gerçekleştirebilmek için ERIC indeksi web sitesinin (www.eric.ed.gov) download sayfasından ERIC veri tabanında indekslenen makale kayıtları her bir yılı baz alacak şekilde ayrı XML dosyası olarak bilgisayara indirilmiş ve kayıt altına alınmıştır. Kayıt altına alınma işleminden sonra ERIC veri tabanından elde edilen büyük veri, programın ilerleyen aşamalarında daha kolay işlenebilmesi amacıyla, Python 
kütüphanelerinden The ElementTree XML API (https://docs.python.org/3/library/xml.etree.elementtree.html) ve Pandas kütüphanelerinden (McKinney vd., 2010) yararlanılarak Pandas data frame veri tipine çevrilmiş ve sırasıyla; Pandas kütüphanelerinden yararlanarak sütun isimlerinin standart hale getirilmesi,Pandas kütüphanelerinden yararlanılarak sütun isimlerinin değiştirilmesi, Pandas kütüphanelerinden yararlanılarak yalnızca analiz için gerekli veri sütunlarının seçilmesi işlemleri gerçekleştirilmiştir. Son olarak, Pandas kütüphanesinin okuma yazma kolaylığı sağladığ dosya tiplerinden biri kullanılarak data frame bilgisayarda kayıt altına alınmıştır. Çalışmanın veri toplama ve analiz süreci işlem adımlarında temele alınan yöntemde İşbulan ve diğerlerinin (2021) çalışmasına başvurulmuştur.

Bu araştırmada ERIC Theasurus'da çalışmaların tanımlanması için kullanılan ve ERIC tarafından "descriptor" olarak isimlendirilen konu başlıkları arasında yer alan "Yükseköğretim" 1. düzey anahtar kelime olarak belirlenmiştir. 2. düzey anahtar kelime olarak çalışma tiplerini tanımlamak amacıyla kullanılan Type değişkenlerinden "Journal Article" seçilmiştir. 3. düzey anahtar kelime olarak ise "descriptor" cinsinden “Geo_TR” alanı belirlenmiştir.

\section{Bulgular}

Araştırmadan elde edilen bulgulara göre, yapılan çalışmalarda 1960’lı yıllardan günümüze kadar özel eğitim ve eğitim teknolojileri ile ilgili makalelerin de yıllara göre doğrusal bir artış/azalış içerisinde olduğu görülse de bu artışta belli zamanlarda bir kırılma meydana geldiği görülmektedir. Ayrıca özel eğitim alanı ile ilgili yazılmış makalelerin özet kısımlarında yer alan metinlerde yer alan trendlerde en fazla yer alan kelimenin "okul" kelimesi olduğu, bu kelimeyi "program”, “çocuk”, “öğretmen”, "need (ihtiyaç)” ve "disability (engel)" kelimelerinin takip ettiği ve eğitim teknolojilerine de özet metinlerinde yer veren makalelerin bulguları arasında "program", "instructional (öğretimsel)", “development (gelişme)", "learning (öğrenme)", "teacher (öğretmen)", "school (okul)", "program”, “development (gelişme)”, “disability (engel)” kelimelerinin olduğu görülmektedir. Çalışmanın en değerli bulguları arasında 1980'ler ve 1990'ların başına kadar "handicapped (özürlü)" kelimesinin özetlerde yer alması, ancak daha sonra bu kelimenin yerini “disability” kelimesine bırakması olduğu söylenebilir. Bununla birlikte özel eğitimde eğitim teknolojileri olarak bilgisayarın sıklıkla kullanılması çalışmanın dikkat çeken bir diğer bulgusudur. Son olarak, geçmişte özel eğitim alanında mesleki eğitim ile ilgili birçok çalışmanın yapıldığı ancak günümüzde bu sayının oldukça düştüğü gözlenmektedir. Çalışma kapsamında elde edilen sonuçlara dayalı olarak çalışmada gelecek çalışmalara ve araştırmacılara aileler ve öğretmen adayları ile daha çok çalışılması gerektiği ile özel eğitimde sıklıkla çalışılan konularda daha fazla eğitim teknolojilerinin kullanılması gerektiğine ilişkin birtakım öneriler de sunulmuştur.

\section{Tartışma}

Bu çalışmada 1960-2019 yılları arasında ERIC veri tabanında özel eğitim ve eğitim teknolojileri konusunu içeren çalışmalar bilimetrik yöntemler ile incelenmiştir. Elde edilen bulgular eğitim teknolojilerinin özel eğitim alanında kullanımına ilişkin genel durumu ortaya koymak ile birlikte dönemsel olarak konu, içerik ve hedef kitle açısından farklılaşmaktadır. Buna göre 1960'l1 yıllardan günümüze kadar ERIC veri tabanında özel eğitim alanı ile ilgili makaleler incelendiğinde yıllara göre bir artış gösterdiği görülmektedir. Ancak bu artışın 2000’li yılların ortalarına kadar devam ettiği, 2004-2005 yılları arasında ise bir kırılma meydana geldiği görülmektedir. Zira, özel eğitim ve eğitim teknolojileri ile ilgili makalelerin de yıllara göre doğrusal bir artış/azalış içerisinde olduğu görülmektedir. Kırılma noktasında özel eğitim alanı ile ilgili yapılan çalışmaların sayısı yaklaşık 400'lerde iken 180'lere kadar düştüğü gözlenmektedir. Bununla birlikte yaşanan bu düşüşte özel eğitim alanı ile ilgili yapılan makalelerin yalnızca iki veya üç tanesinde eğitim teknolojilerinin kullanıldığı görülmektedir. Buna rağmen 2005 yılından itibaren 2011-2012 yıllarına kadar özel eğitim alanında yapılan makale sayısında ciddi bir artış görülmekte olup, 2013 yılında yayınlanan makale sayısında ise yeniden bir düşüş olduğu gözlenmektedir. Elde edilen bulgular bütünüyle değerlendirildiğinde özel eğitim alanında yapılan çalışmalarda iki sefer dalgalanmanın olduğu görülmektedir.

ERIC veri tabanında özel eğitim alanı ile ilgili yazılmış makalelerin özet kısımlarında yer alan metinlerde yer alan trendler incelenmiş olup en fazla yer alan kelimenin "okul” kelimesi olduğu, bu kelimeyi "program", "çocuk", "öğretmen", need (ihtiyaç)" ve "disability (engel)" kelimelerinin (en çok kullanılandan en az kullanılana doğru siralandığında) takip ettiği görülmektedir. Bu bulgu, eğitim teknolojilerine de özet metinlerinde yer veren makalelerin bulguları olan "program", "instructional (öğretimsel)", "development (gelişme)", "learning (öğrenme)", “teacher (öğretmen)", "school (okul)”, "program”, “development (gelişme)”, "disability (engel)” (en çok kullanılandan en az kullanılana doğru sıralandığında) kelimeleri ile birlikte değerlendirildiğinde geçmişten günümüze yapılan çalışmaların okul üzerinde yoğunlaştığını, program ile ilgili yayınlanan makalelerin süreklilik 

ÇERÇEVESINDE INCELENMESI

arz ettiğini söylemek mümkündür. Bununla birlikte eğitim teknolojilerinin de program içerisinde yer edindiği söylenebilir. Nitekim, Sani-Bozkurt (2017) özel eğitimde kullanılacak yardımcı teknolojiler için planlanacak amaç, teknolojik araç, teknoloji destekli yazılım programı, yöntem, teknik ve etkinliklerin hem öğrenen hem de öğreten için oldukça etkili ve eğlenceli teknoloji destekli bir öğrenme ortamı sağlayacağı belirtilmektedir. Şemşit ve diğerleri (2016) engellilere yönelik özel eğitim kurumlarıyla işbirliği içerisinde yapılan programın, engellilerin okuldan işgücü piyasasına geçişini kolaylaştırmayı hedeflediğini; örnek olarak ise Hollanda'da Sosyal İşler ve İstihdam Bakanlığı belediyelerinin engelliler için işgücü piyasasına geçiş programı adı altında bir uygulama yapmaya teşvik ettiğini belirtmektedir. Böylelikle, elde edilen sonuçlar da düşünüldüğünde "okul” ların teknoloji destekli programlar ile özel eğitim alanı için gerçek yaşam becerilerinin kazandırıldığı bir ortam olması fikri oldukça heyecan vericidir. Bununla birlikte, çalışmada çocuk ve öğretmen ile ilgili gerçek yaşam becerilerinin olduğu trendlerin de önemli bir yer tuttuğunu söylemek mümkündür. Bu sonucun elde edilmesinde kullanılan bilgisayar yazılımlarının etkisinin olduğu düşünülmektedir. Öyle ki dil ve konuşma bozukluğu olan çocuklar ve otizm spektrum bozukluğu olan çocukların temel yetersizlik gösterdikleri alanlar olan dil ve iletişim becerilerinin (Heward, 2013) öğretmen önderliğinde kullanılan bilgisayar yazılımları ile kendi istek ve ihtiyaçlarını ifade edebileceği ve cümle kurmaya olanak sağlayabileceği de ifade edilmektedir (Sani-Bozkurt, 2017). Özet metinlerin incelenmesi ile dikkat çeken en önemli bulgunun 1980'ler ve 1990'ların başına kadar "handicapped" kelimesinin özetlerde yer aldığı, daha sonra bu kelimenin yerini "disability” kelimesine bıraktığı söylenebilir. Bu durumun alanyazına yansımasında "özürlü" kavramı yerine "engelli" kavramının tercih edilmesinin etkisi olduğu düşünülmektedir. Öyle ki özürlü kelimesi kusuru, özrü olan, defolu anlamına gelmekte iken; "engelli” kavramı engeli olan veya vücudunda eksikliği olan olarak ifade edilmektedir (Türk Dil Kurumu, 1932). Bununla birlikte herkesin birer engelli adayı olduğunu unutmamak gerekir ki ülkeler bu kavramın kullanılması ile ilgili kanunda birtakım değişikliğe gitmiş̧ir. Örneğin Türkiye Cumhuriyeti Devleti 3 Mayıs 2013 tarihli 28636 sayılı resmi gazetede yayınlanan 6462 sayılı kanun ile daha önceki bazı resmi tanımlarda geçen; özürlü, sakat veya çürük (askere uygun değildir) gibi ibareler yerine engelli ibaresinin kullanılması kanuna bağlamıştır. Benzer şekilde Dünya Sağlık Örgütü'nün (DSÖ) (1980) Yetersizlik, Özürlülük ve Engelliliklerin Uluslararası Sınıflandırılmasına yönelik (International Classification of Impairments, Disabilities and Handicaps-ICIDH) yaptı̆̆ tanımlarda yetersizliği (Impairment) vücudun zihinsel, fiziksel veya işlevsel bozukluğu olarak; bunun yanı sıra özürlülük (disability) yetersizlik sonucu fonksiyonel kapasitede meydana gelen azalma veya kayıp olarak ifade edilirken; engellilik (handicap) bir yetersizlik ya da özürlülük sonucu oluşan, toplum tarafından kişiden beklenen bireysel performans veya durumdan sapmaya neden olan toplumsal bir bozukluk olarak tanımlanmaktadır. Benzer şekilde, geçmişte özel eğitim alanında mesleki eğitim ile ilgili birçok çalışmanın yapıldığı ancak günümüzde bu sayının oldukça düş̧üğü görülmektedir. Binici ve Arı (2014) iş dünyasına geçiş sırasında genel rekabete, meslekî yeteneklerin ön planda tutulmasına ve istihdamda işin gerektirdiği genel rekabet ortamının yaratılması gerekliliğine ilişkin görüşleri ile mesleki eğitimin önemine dikkat çekmektedir. Bu nedenle özel eğitim alanında mesleki eğitim ile ilgili yapılacak çalışmaların gereksinim duyulan kaliteli ve rekabet edebilir bir eğitim olup olmadığı ile ilgili daha fazla çalışmanın yapılması gerekli olabilir. Özel eğitim ile ilgili yer alan makaleler konu açısından incelendiğinde en fazla öne çıkan konunun "disabilities" olduğu görülse de "elementary secondary education (ilköğretim/orta öğretim)", "federal legislation (federal müfredat)", "special needs students (özel eğitim gereksinimi olan öğrenciler)", "special education teachers (özel eğitim öğretmenleri)", teaching methods (öğretim yöntemleri)", "mainstreaming (kaynaştırma)", "learning disabilities (öğrenme güçlükleri)" ve "educational legislation (eğitim mevzuatı)" (çoktan aza doğru sıralandığında) konuları üzerine de yoğunlaştığı görülmektedir. $\mathrm{Bu}$ bulgu özel eğitim alanında eğitim teknolojilerinin kullanıldığı makalelerde ele alınan (çoktan aza doğru sıralandığında) "disabilities (engel)", "elementary secondary education (ilköğretim/orta öğretim)", "teaching methods (öğretim yöntemleri)", "computer assisted instruction (bilgisayar destekli öğretim)", "technology uses in education (eğitimde teknoloji kullanımı)", "assistive technology (yardımcı teknoloji)", "higher education (yükseköğretim)", "computer uses in education (eğitimde bilgisayar kullanımı)", "special needs students (özel eğitim gereksinimi olan öğrenciler)" ve "special education teachers (özel eğitim öğretmenleri)" konuları ile birlikte değerlendirildiğinde özel eğitim alanında "bilgisayar" in yardımcı ve tek eğitim teknolojisi aracı olarak öne çıktığı gözlenmektedir. Yapılan çalışmalar değerlendirildiğinde her ne kadar "assistive technology" konusu da ele alınsa da burada kullanılan eğitim teknolojisinin yine "bilgisayar" olduğu görülmektedir. Özak ve Avcığlu (2007) çalışmasında zihinsel yetersizliği olan öğrencilere okuma becerilerinin öğretiminde bilgisayar aracılığıyla sunulan eş zamanlı ipucuyla öğretimin etkililiğini ortaya koymaktadır. Benzer şekilde, öğretim teknolojilerinin tarihsel gelişimine bakıldığında mobil öğrenme, artırılmış gerçeklik, sanal gerçeklik vb. gelişmelerin olduğu görülmektedir. Bununla birlikte mobil uygulamalar, akıllı kişisel asistanlar, artııılmış gerçeklik uygulamaları gibi teknolojilerin özel eğitime yardımcı teknolojiler olarak kullanılabileceği belirtilse de (Sani-Bozkurt, 2017) uygulamaya yönelik yapılmış çalışmalar son zamanlarda yapılmaya başlanmış olup oldukça sınırlıdır (Karanfiller 
vd., 2017; Subakan \& Koç, 2019; Yaman vd., 2016). ERIC veri tabanı eğitim indexine ait bir veri tabanı olması açısından elde edilen bulguların alanyazına yön vererek büyük resmin sunulması açısından oldukça katkı sağlayacağ söylenebilir. Geçmişten günümüze yapılan çalışmalarda özel eğitim alanında "bilgisayar" haricinde çok fazla eğitim teknolojilerinin kullanılmadığı görülmekte ve "mobil teknoloji", "artırılmış gerçeklik" ve "sanal gerçeklik" alanında sığ kaldığı ve yeterince çalışılmamış olduğu söylenebilir. Ayrıca yapılan çalışmalarda ele alınan "assistive technology" konusu ile birlikte artırılmış gerçeklik ve sanal gerçeklik çalışmalarının oldukça işe yarayacağı da düşünülmektedir.

Özel eğitim alanında yapılan makaleler hedef kitle değişkenine göre incelendiğinde makalelerin hedef kitlesinin çoğunluğunu "practitioners" lar oluştursa da bu çoğunluğu "teachers (öğretmenler)", policymakers (politikacılar)", "administrators (yöneticiler)" ve "parents (ebeveynler)" takip etmektedir. Benzer durum, eğitim teknolojilerinin birlikte çalışıldığı makalelerde de yer almaktadır. Ancak burada farklı olarak "researchers" lar da eğitim teknolojilerinin özel eğitim alanında kullanıldığı makalelerde hedef kitle arasında yer almaktadır. Elde edilen bulgular doğrultusunda hedef kitlenin öğretmen adayları olduğu çalışmalara ihtiyaç duyulduğu gözlenmektedir. Ayrıca eğitim teknolojilerinin özel eğitim alanında kullanıldığı çalışmaların da hedef kitlesini aileler oluşturacak şekilde gerçekleştirilmesine ihtiyaç olduğu görülmektedir. Nitekim, Sani-Bozkurt (2017) etkili bir öğretim sunabilmede yardımcı teknolojileri planlama sürecinde yardımcı teknolojiyi kullanacak uzman, aile ve ilgili diğer uzmanlar birlikte karar vermesi gerektiğini ifade etmektedir. Cavkaytar (1999) da ailelerin çocuklarının eğitimine aktif katılımına yönelik araştırmaların, aileye, çocuğa ve eğitim sürecine önemli katkılar getirdiğini ifade etmektedir.

Eğitim teknolojilerinin özel eğitim alanı ile birlikte çalışıldığı makaleler geçmiş günümüze incelendiğinde en fazla çalışılan konunun "disabilities" olduğu; bu birlikteliği özel eğitimde "teaching methods", "technology uses in education", "higher education", "special needs education" gibi konularda eğitim teknolojileri ile beraber çalş̧lan makalelerin oluşturduğu gözlenmektedir. Her ne kadar özel eğitimde eğitim teknolojilerinin kullanılmasını konu edinen çalışmaların birlikteliğinden bahsetmek mümkünse de özel eğitim alanında eğitim teknolojileri disiplininden hiç yararlanılmamış konular da bulunmaktadır. Örneğin 1960'lardan günümüze kadar özel eğitim alanında sıklıkla tercih edilen "due process" konusu eğitim teknolojileri disiplininden yararlanılmadan çalışılmıştır. Yapılan çalışmalarda "due process" ile ilgili yaklaşık 380 tane çalışmanın olduğu gözlense de bu çalışmaların hiçbirinde eğitim teknolojilerinden faydalanılmamıştır. Ayrıca "labeling (etiketleme)", "self concept (benlik kavramı)", "federal regulation (federal düzenleme)", "behavioral objectives (davranışsal hedefler)" gibi konular da özel eğitim alanında sıklıkla çalışılmış olsa da bu konuların çalışılmasında eğitim teknolojilerinden yararlanılmadığı görülmektedir.

\section{Sınırlılıklar ve Öneriler}

Bu çalışma 1960-2019 yılları arasında eğitim teknolojileri ve özel eğitim alanında ERIC veri tabanında yapılan çalışmalar ile sınırlıdır. Özel eğitim ve eğitim teknolojileri konusunu içeren çalışmaların bilimetrik yöntemler ile incelendiği bu çalışmada elde edilen bulgulara dayalı olarak sıklıkla çalışılan konularda eğitim teknolojilerinin kullanılması gelecek çalışmalarda önerilmektedir. Bu öneri esasında eğitim teknolojileri denildiğinde bu kavramın salt bilgisayar olarak algılanmaması gerektiği önemle vurgulanmaktadır. Öğretim teknolojilerinin tarihsel gelişimi incelenerek bu doğrultuda müfredat programlarının yenilenmesi ve teknolojik gelişmişlikten faydalanılarak düzenlenmesi önerilmektedir. Gelişen teknolojiler 1şı̆̆ında eğitim ortamlarında kullanılan teknolojiler gerekli adaptasyon çalışmaları yapıldıktan sonra eğitim-öğretim sürecine entegre edilmelidir. Özellikle özel eğitim alanında en çok araştırılan eğitim teknolojisi konularına ilişkin bulgular dikkate alındığında, Bireyselleştirilmiş Eğitim Planlarının (BEP) sadece bilgisayar veya yardımcı teknolojilerle değil eğitim teknolojileri ve öğretim yöntemleri ile de bütünleştirilmesi önerilmektedir. Eğitim alanındaki gelişmeler göz önüne alındığında, öğretim elemanları, araştırmacılar ve uygulayıcılar, Bilgisayar ve Öğretim Teknolojileri Eğitimi (BÖTE) alanındaki uzman kişilerle işbirliği yaparak öğrencilerin gelişimsel ve mesleki özelliklerine dayalı en etkili eğitim teknolojisini ihtiyaçlar temelinde uygun öğretim yöntemi ve özel eğitim alanlarıyla bütünleştirebilirler. $\mathrm{Bu}$ süreçte ailelerin de oldukça fazla desteği olabileceği düşünülmektedir. Öyle ki özel gereksinimi olan bireylerin eğitim teknolojileri ile zenginleştirilmiş öğrenme ortamlarının yalnızca okul ortamı ile sınırlı olmaması gerektiği, kazandırılacak beceri ve yeterliliklerin uygun öğrenme ortamlarının düzenlemesi ile ailelerin de desteği ile birlikte gerçekleştirilmesi öngörülmektedir. Çalışmalarda hedef kitlenin aileler olduğu kadar öğretmen adaylarının da olduğu planlamaların yapılması gelecek araştırmacılara önerilmektedir. Eğitim teknologlarının özel eğitim alan uzmanları, özel eğitim alanında öğrenim görmekte olan öğretmen adayları, akademisyenler, program geliştiriciler ve yöneticiler ile daha sık bir araya gelerek yönetişim esasına dayalı işbirlikli uygulamalar ile ihtiyaçları ve beklentileri karşılayacak teknoloji destekli öğrenme ortamlarının 
geliştirilmesine katkı sağlamalıdır. Son olarak, eğitim teknolojilerinin farklı disiplinler açısından ele alınarak, ele alındığı dönemlerin ayrıntılı bir şekilde incelenmesinin de öğretim ortamlarındaki ve öğrenme süreçlerindeki eğilimlerin ortaya konulmasında önemli görüldüğünden gelecek çalışmalara ve araştırmacılara önerilmektedir.

\section{Yazarların Katkı Düzeyleri}

Çalışmada büyük verinin elde edilmesi ve analizi süreci ile çalışmanın fikri ve yöntem bölümü üçüncü yazara aittir. Çalışmada elde edilen verilen bulgulara dönüştürülmesi ve yorumlanması ikinci yazar tarafindan gerçekleştirilmiştir. Çalışmanın diğer kısımları giriş, literatür, sonuç, tartışma ve sınırlılıklar ilk yazar tarafından yapılmıştır. 